\title{
Erratum
}

\section{Effects of trade barriers and cultural distance on the domestic market share in the film industry - ERRATUM}

\author{
YONG-JAE CHOI, CHUNG-KI MIN AND CHANYUL PARK
}

doi: 10.1017/S1474745619000077, published by Cambridge University Press, 14 May 2019.

The above article was published with incorrect author affiliations. The correct information is as follows:

Yong-Jae Choi and Chung-ki Min are affiliated with Hankuk University of Foreign Studies, Korea, and Chanyul Park is affiliated with Gyeongnam Development Institute, Korea.

The error has since been rectified in the online PDF and HTML copies.

\section{Reference}

Choi, Y.-J., Min, C.-k., and Park, C. (2019). Effects of Trade Barriers and Cultural Distance on the Domestic Market Share in the Film Industry. World Trade Review, 1-14. Cambridge University Press. 